Julijana Vasiljević ${ }^{1}$

SCIENTIFIC REVIEW ARTICLE

University of Nis, Faculty of Electronic Engineering, Nis

Đurđica Vukajlović doi:10.5937/ekonomika1504109V

University Business Academy,

Received: October 10, 2015

Faculty for Applied Management, Economy and Finance, Belgrade

DraganVasiljević ${ }^{3}$

University of Nis, Faculty of Electronic Engineering, Nis

\title{
PROPOSED METHODS OF PREDICTING ACHIEVEMENT OF STUDENTS THAT IS IMPORTANT FOR THE FUTURE BUSINESS PERFORMANCE
}

\begin{abstract}
Today's business cannot be imagined without the support of IT developments, information and knowledge are the two basic resources for successful business. In this context, it is critical comprehension and understanding of the role of teachers, schools and families in the education process, especially in primary education as the basis of further development of the individual personality, and therefore the development of society. The paper summarizes the application of Data Mining techniques in the field of primary education, with special reference to the method of binary logistic regression. It also presents the results of research and gives a suggestion of appearance and functionality of Web-based system for mining data from different sources, with emphasis on the application of such a system for adequate measures for the improvement of the level of achievement of primary school students. The proposed system would be based on the results of data mining included providing support to schools and parents in making a decision on taking measures to improve the level of achievement and optimal choice of future profession.
\end{abstract}

Key words: binary logistic regression, the educational process, achievement

JEL classification: C 520, I 00

\section{ПРЕДЛОГ МЕТОДЕ ПРЕДВИЪАЊА ПОСТИГНУЋА УЧЕНИКА ОД ЗНАЧАЈА ЗА БУДУЋИ ПОСЛОВНИ УЧИНАК}

\section{Апстракт}

Данашье пословање немогуће је замислити без подрике информатичких достигнућа, а информачије и знање два су основна ресурса за успешно пословање. У овом контексту од кључне је важности разумевање и

\footnotetext{
1 julija2921968@gmail.com

2 vukajlovicdj@gmail.com

3 vasiljevicdj68@gmail.com
} 
схватағе улоге наставника, школе и породице у образовно-васпитном проиесу, посебно у основном образоваюу као темељу будућег индивидуалног развоја личности, а самим тим и развоја друштва у целини. У раду је дат преглед примене техника дата миниг-а у области основног образовања и васпитања, с посебним освртом на метод бинарне логистичке регресије. Такође, приказани су резултати истраживања и дат је предлог изгледа и функиионалности Шеб базираног система за миниг података из различитих извора, са освртом на примену таквог система за адекватно предузимање мера за побољшање нивоа постигнућа ученика основних школа. Предложени систем би на основу резултата добијених дата мининг-ом пружао подрику школи и родитељима приликом доношења одлуке о предузимању мера за унапређење нивоа постигнућа и оптималног избора будуће професије.

Кључне речи: бинарна логистичка регресија, образовно-васпитни прочес, nостигнуће

\section{Introduction}

A way that could increase the success of using databases to extract useful information, improve business functionality and operation of an organization is called the Data Mining (hereinafter: DM). Data mining is the search for valuable information in large volumes of data. Data mining is a research and analysis of large amounts of data using automatic or semi-automatic method in order to discover meaningful regularities. There is no recipe for successful DM that will surely result in finding valuable information. DM probability of success will increase if you follow the steps of the process of data mining as follows: the first step is defining of a "business" issue; the second step is the preparation of data that includes the determination of the necessary data transformation, sampling and data evaluation. Modeling is the third step that includes selecting methods of data mining, development and evaluation of models. The fourth step is implementation, which includes the interpretation and use of results. In studying the level of educational attainment, one of the main questions is to what extent and on which memorials teachers, schools, students and their environment we can explain or predict school success and the level of student achievement.

When educational institutions apply DM existing data they can detect a new, useful and potentially important information that would otherwise remain as a record in a database. The aim of the research presented in this paper is to analyze the possibility of applying techniques DM in the educational system of elementary schools, relying on open data on schools in perspective of "unique education information system of the Republic of Serbia", data from existing databases within the school, as well as other external and internal data sources. 


\section{The importance of measuring student achievement for their future business success}

Planning of labor force and directing of education system in direction of discovering achievement of students is imperative of present time. Without quality of education, there is no quality of knowledge, no progress of society, where education has a function of individual personal development and development of future generations (Sučević \& Kerić, 2015) that generate successful economy. Intensive changes of social and economic occasions on the global level have caused changes in education system of many countries (Tomić, Spasenović \& Hebib, 2015; Ilić-Rajković, 2015). Today’s practice shows that there are rarely changes in curriculum for primary education, although there are attempts for their innovation (Mikanović, 2014) in order to find the best way for enabling student to get knowledge needed in the economy of a country.

Today is inevitable connection between education system and economic system. Obtaining information about teaching, success in its implementation, one can predict outcome and result that students will contribute to the community as its future active working members. The process of education includes self-education and the influence of environment on education (Paszek, 2012). By transferring not only systematic acquired knowledge, but also the development of certain skills such as leadership, cooperation within the teams, communication with the environment, negotiation and risk taking (Dietl, 1997) it is possible to direct and measur certain achievements in direction of their opportunities for future business orientation and results. Unemployment is one of the biggest problems of our society which is result of the transition to the market concept of economic activity and the affirmation of labor market (Milosevic \& Stojković, 2013). This problem can be solved by determining the effect and mode of education at the earliest stage.

Economic development has always been based on the use of knowledge, but extent of the importance of knowledge for the development of economic processes has changed over the years (Nijkamp, \& Siedschlag, 2011), so knowledge has to be predicted in order to assess future business base in economy. Educated and adequately trained population can create, share and use knowledge, while efficient innovation system of enterprises, research centers and other organizations may be incorporated into the growing activities of global knowledge (Ilic \& Nedic, 2014) in order to measure knowledge and achievement on adequately way and to direct it to the needs of the economy.

\section{Methods of DM}

Methods of data mining is used to build a model according to which we will the to try to determine new information, give meaning relations, conditionality and cohesion for available data.

\subsection{Summary of basics methods of DM}

Basic methods used by the DM algorithms analysis fall into two basic groups (Han, Kamber \& Data 2001): DM method using supervised algorithms and unsupervised algorithms. 
Supervised algorithms are those in which, to build models, are used the data from in advance known groups in which data belong, and then on the basis of the constructed model predicts group which will belong to unknown data. These gathering methods belong to the classification of data and regression methods.

Non-supervised algorithms are based on the given data form groups of data, without prior knowledge about in which group data might belong. This set of methods belongs to the grouping and association rules.

\subsection{Regression}

Regression is a method that predicts the value of numeric attributes. It is based on the known values of attributes of the given data with a goal to determine model parameters, and then on the basis of the model parameters we can determine unknown attribute values of new data.

The regression model with their evaluation methods is suitable for areas where the classification codes of prediction are categorical (discrete, unsorted) variables. Regression is used to predict the missing or unavailable numerical values before the tag class. Prediction refers to both types of predictions, numerical and class prediction.

Regression analysis is a statistical method that is used primarily for numerical forecasting, and as such includes the identification of trends over the available data (Goharian \& Grossman, 2003).

There are several different types of regression in statistics, but the more general idea is to create a model that maps values of predictors in a way that the possibility of error in forecasting is the lowest. Basic types of regression are: linear regression, multiple regression, logistic regression, nonlinear regression.

\subsubsection{Linear regression}

Linear regression is the simplest form of regression in which the value of the dependent random variable $\mathrm{Y}$ is defined as a linear function of the predictive variables $\mathrm{X}$ :

$$
\mathrm{Y}=\alpha \mathrm{X}+\beta
$$

where the regression coefficients $\alpha$ and $\beta$ are determined by the method of least squares.

Let it be the given set of samples U, where each sample is shown as a twodimensional vector $\left(x_{i}, y_{i}\right)$. The number of samples is $u$.

Ratios $\alpha$ and $\beta$ are determined as:

$\beta=\frac{\sum_{i=1}^{u}\left(x_{i}-\bar{x}\right)\left(y_{i}-\bar{y}\right)}{\sum_{i=1}^{u}\left(x_{i}-\bar{x}\right)^{2}}, \alpha=\bar{y}-\beta \bar{x}$

Values $\bar{x}$ and $\bar{y}$ are values: $\quad \bar{x}=\frac{\sum_{i=1}^{u} x_{i}}{u} \quad \bar{y}=\frac{\sum_{i=1}^{u} y_{i}}{u}$ 


\subsubsection{Multiple regression}

Multiple regression is an extension of linear regression. In contrast to the linear regression analysis involves more than one predictive variable. The dependent variable $\mathrm{Y}$ is defined as a linear function of the multidimensional vector predictors. The general form of multiple regression is:

$$
y=\alpha_{1} x_{1}+\ldots \alpha_{n} x_{n}+\beta_{1}
$$

Where the parameters $\alpha$ and $\beta$ are determined by the method of least squares.

\subsubsection{Logistic regression}

Logistic regression is an extension of linear regression with the restriction that the range of values that can take the dependent variable Y can only be from the interval $[0,1]$.

The logistics function thus modeled as a linear function of the probability of predictive variables, the general form is:

$$
y=\frac{1}{1+e^{-x}}
$$

\subsubsection{Nonlinear regression}

If the variables in the model does not show a linear, polynomial rather than dependence, it is a polynomial dependence that must be reduced to a linear form and the matter further as linear regression.

Given the fact that there is no mathematical model to accurately determine the level of achievement, which should be directly related to educational standards, the author of this paper made a draft of a mathematical model to determine the level of school achievement which in itself consists of two components: the overall success during the education and the result of the final exam. The results obtained in this manner were used in making models of data analysis based on the method of binary logistic regression. The proposal and explained the method for setting the level of achievement of primary schools is given in the third chapter of this work.

\section{Suggestions for ways of determining the level achievements of elementary school}

Quality framework for evaluating the work of educational institutions in the Republic of Serbia includes 30 standards and 158 indicators (Regulations on standards of quality of work of educational institutions, "RS Official Gazette" No. 7/11) distributed in seven key areas of the school: The school program and annual plan of work, teaching and learning achievements of students, support to students, ethos, work organization and management and resources.

Results obtained by the process of evaluation is primarily used to further the work of the institution, but can also be used as a mean of reporting on the work of educational institutions as well as other target audiences. 


\subsection{Educational standards and levels of achievement}

Educational standards are:

- a series of statements that describe the knowledge and skills that we expect the student to demonstrate a certain level of achievement;

- descriptions of essential knowledge and skills that students should have at the end of a certain level of education.

Levels of achievement are:

- Basic Level - At a basic level requirements are described which represent the basic level of knowledge, abilities and skills, and it is expected that more than $80 \%$ of students achieve this level.

- Intermediate level - At the middle level there are described claims that an average student can demonstrate. It is expected that about $50 \%$ of the students reach or exceed this level.

- Advanced level - At the advanced level there are described requirements that can show students who are likely to be successful in secondary education. It is expected that about $25 \%$ of students achieve this level.

\subsection{Determination of achievements levels of elementary schools}

The basic idea of how to determine the level of achievement of primary school students is visually displayed as follows:

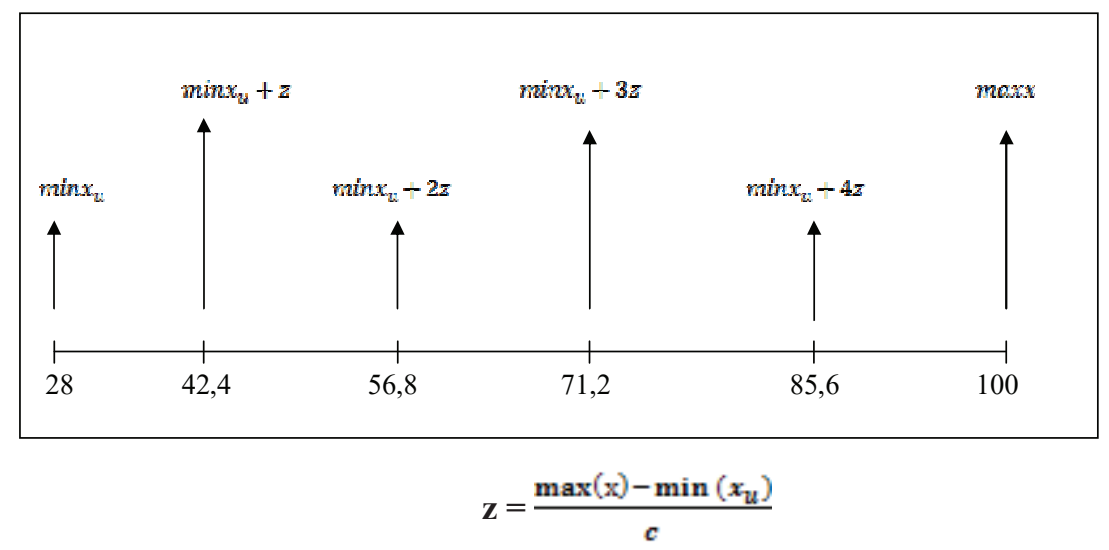

Whereas: $\quad \mathrm{x}-$ the overall success of primary school

$\mathrm{x}_{u}$ - success in elementary school (average of all grades)

$x_{z}-$ the success of the final exam

$\mathrm{c}-$ scale level of achievement (in the case of a five-point scale is the number 5)

$\mathrm{z}$ - coefficient of achievements

The initial value of the scale is $\min x_{u}$ which represents the minimum student achievement during primary education for sixth, seventh and eighth grade. According to the applicable criteria, the average score of students in the sixth grade is multiplied by the number 4 , for the seventh grade is multiplied by the number 5 and the eighth grade 
is multiplied by the number 5 .

If the student has had an average grade in these grades 2.00 (which allows the release of the final test) then the summation of points is 28 , then 28 is the minimum number of points that a student can get based on the achieved results during education.

Suppose a student in the final test had 0 points, then the total score or overall success of primary school $\mathbf{x}=x_{u}+x_{z}$ equal to 28 points, on the contrary, if the student has had the maximum number of points based on the performance ( 70 points) and the maximum number of points in the final test (30) then the maximum number of points is 100 .

In this way, we determined the initial minimum and maximum value on a scale of achievement levels.

On the basis of the criteria for numerically evaluating the success of students is determined by the scale of levels of student achievement "c" from 1 to 5, which is directly related to levels of achievement standards.

The difference between the maximum number of points and the minimum number of points is:

$$
\mathbf{Z}=\frac{\max (x)-\min \left(x_{u}\right)}{c}
$$

Divided with defined levels of achievement scale represents a coefficient of achievements, which in this particular case is 14.4.

Taking into account the criteria for numerically evaluating the success of students is determined by the scale of levels of student achievement "c" from 1 to 5 (which is directly related to levels of achievement standards).

If the success of students in the school (which integrates the average of all grades and success in the final examination) is between 28 and 42.4 points, it means that the specified requirements are achieved at the basic level of achievement.

If the success of students in the school is between 42.4 and 56.8 points, it means that the specified requirements are achieved at the basic level of achievement.

If the success of students in the school is between 56.8 and 71.2 points, it means that the specified requirements are achieved at the basic level of achievement and partly $(20 \%)$ at the middle level of achievement - middle lower level of achievement.

If the success of students in the school is between 71.2 and 85.6 points, it means that the specified requirements are achieved at the basic level of achievement and mostly $(80 \%)$ of the middle level of achievement - medium higher level of achievement.

If the success of students in the school between 85.6 and 100 points, it means that it achieved an advanced level of achievement.

Based on the determined level of achievement and achieved general success (success during their education and success in the final test) it is possible to assess the condition of the school as follows:

- Elementary School is classified as a school whose work does not achieve the requirements of the basic level of achievement,

- Elementary School is classified as a school whose work achieves the requirements of the basic level of achievement,

- Elementary School is classified as a school whose work achieves the demands on primary and secondary lower level of achievement,

- Elementary School is classified as a school whose work achieves the demands 
on primary and secondary higher level of achievement and

- Elementary School is classified as a school whose work achieves the requirements of the advanced level of achievement.

Estimated state and the classification should identify key problems, causes and consequences đ to the educational work of the school.

\section{Overview of the results of binary logistic regression}

For the purposes of research and implementation of DM method of binary logistic regression collected data are sorted into groups, as follows:

The first set of data

The first set of data is obtained from a survey of teaching staff of eight elementary schools from the territory of the City of Belgrade and the municipalities of Cukarica, Obrenovac and Rakovica .

Questionnaire - attitudes Likert scale 1-5, (8 independent and 51 dependent variable),

Total 302 respondents (2 surveys are invalid), processed in the program tool "SPSS" 300 polls.

Second group of data

The second group of data is obtained from a survey of parents whose children attend primary school in the area of the City of Belgrade and the municipalities of Cukarica, Obrenovac and Rakovica

Questionnaire - Likert scale paragraphs 1-5 (7 independent and 32 dependent variables).

Total of 320 respondents ( 20 surveys were invalid), processed in the program tool "SPSS" 300 polls.

Third set of data

With regard to the defined position of the Ministry of Education, Science and Technological Development of the Republic of Serbia to the final examination determines whether a student during its education mastere the knowledge and skills from Serbian, or mother tongue, mathematics and the natural and social sciences (biology, geography, history, physics and chemistry).

The third group of data consists of information about:

- the total number of the employee of the teaching staff at eight elementary schools from the territory of the City of Belgrade and the municipalities of Cukarica, Obrenovac and Rakovica,

- the total number of pupils in these schools,

- the number of eighth-grade students at the end of the school year 2014/2015, the results achieved (grade point average) during training in mathematics and Serbian and mother tongue

- $\quad$ results of the final exam (students' mastery of knowledge and skills). 
After the data collection and transformation of data into the software package "SPSS" for the first and second sets of data it was performed factor analysis as follows:

- Exploratory factor analysis and

- Confirmatory factor analysis.

Exploratory factor analysis of the first group of data acquired through questionnaires of teaching staff of eight elementary schools set aside a total of 13 factors of 8 independent and 51 dependent variable, where the authors of this work, for the comparative analysis of the data of the first and second groups of data, the 7 factors are named: FN1 - method of operation and organization of the teaching classes (MRON), FN2 - social factor (SF), FN3 - quality of work (KR), FN4 - the use of ICT in teaching (ICT), FN5 - syllabus (ON), FN6 - engagement of parents (AR) and FN7 - content of textbooks (SU).

Using the confirmatory factor analysis it was performed data extraction method "PCA - (Principal component analysis), which was verified by grouping variables, and it confirmed that these variables are essentially grouped around the above factors.

Variables with a similar attitude or sense of the respondents for FN1 are V3 - In your opinion, are the classes held successfully, V4 - In your opinion, your colleagues perform successful classes, V8 - The success of the students from your course is at a high level, V10 - Physical activity positively affect the learning ability of the students, V14 - Students are active in classes V15 - Students know how to applicate learned lessons, V19 - Are you satisfied with the working conditions and V40 - Teaching by topics has advantages over the teaching of particular cases.

Results of confirmatory factor analysis, total factor Explanation of variables: FN1 - the methods of teaching (MRON) are shown in Table 1.

Table 1. Display of results confirmatory factor analysis for teaching staff

\begin{tabular}{|l|r|r|r|r|r|r|}
\hline \multirow{2}{*}{ Component } & \multicolumn{3}{|c|}{ Initial Eigenvalues } & \multicolumn{2}{|c|}{ Extraction Sums of Squared Loadings } \\
\cline { 2 - 6 } & Total & $\begin{array}{r}\text { \% of } \\
\text { Variance }\end{array}$ & $\begin{array}{c}\text { Cumulative } \\
\text { \% }\end{array}$ & Total & $\begin{array}{r}\text { \% of } \\
\text { Variance }\end{array}$ & $\begin{array}{c}\text { Cumulative } \\
\%\end{array}$ \\
\hline 1 & 3.759 & 46.992 & 46.992 & 3.759 & 46.992 & 46.992 \\
2 & .913 & 11.409 & 58.401 & & & \\
3 & .848 & 10.594 & 68.995 & & & \\
4 & .771 & 9.638 & 78.633 & & & \\
5 & .691 & 8.640 & 87.272 & & & \\
7 & .589 & 7.363 & 94.635 & & & \\
8 & .239 & 2.990 & 97.624 & & & \\
\hline
\end{tabular}

Source: Author

Table 2. Presentation of the component matrix and confirmed grouping of these variables around a single factor. 
Table 2. Component Matrix

\begin{tabular}{|c|c|}
\hline & Component \\
\cline { 2 - 2 } & 1 \\
\hline V10 & .620 \\
V14 & .711 \\
V15 & .809 \\
V19 & .521 \\
V40 & .577 \\
V8 & .515 \\
V3 & .839 \\
V4 & .801 \\
\hline
\end{tabular}

Source: Author

Factor analysis was performed using the same method for the second group of data obtained in the survey of parents whose children attend primary school.

The results of confirmatory factor analysis are preserved in programming tool "SPSS" as a variable for building a model of binary logistic regression.

As an important factor for predicting the level of achievement the author of this work is carried out comparative analysis FN6 - involvement of parents (on teachers' opinions) and FR6 - involvement of parents (parents' attitude) using binary logistic regression.

Confirmatory factor analysis confirms that the variables V16, V21, V22 are grouped around a single factor, shown in Table 3.

V16 - Do you have regular contact with teaching staff of the school in which your child is being educated,

V21 - Have you ever proposed to teachers in any way how the educational process should be improve and

V22 - Does your child get enough attention at school by teachers?

Table 3. Results of confirmatory factor analysis

\begin{tabular}{|l|l|}
\hline & Component \\
\cline { 2 - 2 } & 1 \\
\hline V21 & .928 \\
V22 & .982 \\
V16 & .976 \\
\hline
\end{tabular}

Source: Author

Results of binary logistic regression on the attitude of parents to FR6 factor - the involvement of parents in relation to the level of achievement are shown in Table 4. 
Table 4. Showing results of binary logistic regression on the attitude of parents to factor FR6

\begin{tabular}{|c|c|c|c|c|c|c|c|c|c|}
\hline & $B$ & SE & Wald & $\mathrm{df}$ & $\mathrm{Sig}$ & $\operatorname{Fxn}(B)$ & $95 \%$ C.L & $\mathrm{EXP}(\mathrm{B})$ \\
\hline \multirow{4}{*}{ Step } & V16 & 1.251 & 767 & 2.662 & 1 & 103 & 3495 & $\frac{1017}{777}$ & 15716 \\
\hline & $\mathrm{V} 21$ & 148 & 285 & 271 & 1 & 603 & 160 & 664 & 2026 \\
\hline & V22 & -1.387 & .771 & 3.233 & 1 & .072 & .250 & \multirow[t]{2}{*}{.055} & \multirow{2}{*}{1.133} \\
\hline & Constant & .427 & .257 & 2.760 & 1 & .097 & 1.532 & & \\
\hline
\end{tabular}

Source: Author

Descriptive statistics of variables (V16, V21, V22) is shown in Tables 5, 6 and 7.

Table 5: Descriptive statistics of variables V16

\begin{tabular}{|c|c|c|c|c|c|}
\hline & & Frequency & Percent & Valid Percent & Cumulative Percent \\
\hline \multirow{6}{*}{ Valid } & 1.00 & 195 & 64.8 & 64.8 & 64.8 \\
\hline & 2.00 & 9 & 3.0 & 3.0 & 67.8 \\
\hline & 3.00 & 33 & 11.0 & 11.0 & 78.7 \\
\hline & 4.00 & 24 & 8.0 & 8.0 & 86.7 \\
\hline & 5.00 & 40 & 13.3 & 13.3 & 100.0 \\
\hline & Total & 301 & 100.0 & 100.0 & \\
\hline
\end{tabular}

Source: Author

Table 6: Descriptive statistics of variables V21

\begin{tabular}{|rr|r|r|r|r|}
\hline & Frequency & Percent & Valid Percent & Cumulative Percent \\
\hline \multirow{4}{*}{ Valid } & 1.00 & 217 & 72.1 & 72.1 & 72.1 \\
& 2.00 & 28 & 9.3 & 9.3 & 81.4 \\
& 3.00 & 56 & 18.6 & 18.6 & 100.0 \\
& Total & 301 & 100.0 & 100.0 & \\
\hline
\end{tabular}

Source: Author

Table 7: Descriptive statistics of variables V22

\begin{tabular}{|c|c|c|c|c|c|}
\hline & & Frequency & Percent & Valid Percent & Cumulative Percent \\
\hline \multirow{6}{*}{ Valid } & 1.00 & 198 & 65.8 & 65.8 & 65.8 \\
\hline & 2.00 & 8 & 2.7 & 2.7 & 68.4 \\
\hline & 3.00 & 28 & 9.3 & 9.3 & 77.7 \\
\hline & 4.00 & 23 & 7.6 & 7.6 & 85.4 \\
\hline & 5.00 & 44 & 14.6 & 14.6 & 100.0 \\
\hline & Total & 301 & 100.0 & 100.0 & \\
\hline
\end{tabular}

Source: Author

Based on these results we can conclude that regular contact of parents with teaching staff at the school have a positive impact on improving the level of student achievement to a significant extent, the proposals on working methods also have a positive impact on the improvement of the level, but to a lesser extent, the lack of attention to students by teachers greatly decreases the level of education (applies to gifted students and students with special needs). 
As described above, after the binary logistic regression, it is indicated that the probability of the level of achievement for the analyzed residents is 0.41 , and it can be increased by increasing the activity of parents both at the individual and the generalschool level.

After exploratory factor analysis, confirmatory analysis confirmed the obtained results, in the table 8 .

Table 8: Showing results of confirmatory analysis

\begin{tabular}{|c|c|}
\hline & 1 \\
\hline V24 & .864 \\
\hline V25 & .864 \\
\hline
\end{tabular}

Source: Author

Descriptive statistics of variables (V24, V25) is shown in Tables 9 and 10.

Table 9. Descriptive statistics of variables V24

\begin{tabular}{|c|c|c|c|c|c|}
\hline & & Frequency & Percent & Valid Percent & Cumulative Percent \\
\hline \multirow{5}{*}{ Valid } & 1.00 & 40 & 13.3 & 13.3 & 13.3 \\
\hline & 2.00 & 152 & 50.7 & 50.7 & 64.0 \\
\hline & 3.00 & 84 & 28.0 & 28.0 & 92.0 \\
\hline & 4.00 & 24 & 8.0 & 8.0 & 100.0 \\
\hline & Total & 300 & 100.0 & 100.0 & \\
\hline
\end{tabular}

Source:Author

Table 10. Descriptive statistics of variables V250

\begin{tabular}{|c|c|c|c|c|c|}
\hline & & Frequency & Percent & Valid Percent & Cumulative Percent \\
\hline \multirow{6}{*}{ Valid } & 1.00 & 46 & 15.3 & 15.3 & 15.3 \\
\hline & 2.00 & 173 & 57.7 & 57.7 & 73.0 \\
\hline & 3.00 & 32 & 10.7 & 10.7 & 83.7 \\
\hline & 4.00 & 39 & 13.0 & 13.0 & 96.7 \\
\hline & 5.00 & 10 & 3.3 & 3.3 & 100.0 \\
\hline & Total & 300 & 100.0 & 100.0 & \\
\hline
\end{tabular}

Source: Author

Results of binary logistic regression on the attitude of the teaching staff by a factor FN6 - the involvement of parents in relation to the level of achievement are shown in Table 11. 
Table 11. Binary logistic regression on the attitude of the teaching staff by a factor FN6

\begin{tabular}{|c|c|c|c|c|c|c|c|c|c|}
\hline & & \multirow{2}{*}{ B } & \multirow{2}{*}{ S.E. } & \multirow{2}{*}{ Wald } & \multirow{2}{*}{ df } & \multirow{2}{*}{ Sig. } & \multirow{2}{*}{$\operatorname{Exp}(B)$} & \multicolumn{2}{|c|}{ 95\% C.I.for EXP(B) } \\
\hline & & & & & & & & Lower & Upper \\
\hline \multirow{3}{*}{ Step 1} & V24 & -.037 & .168 & .048 & 1 & .826 & .964 & .693 & 1.340 \\
\hline & V25 & .097 & .137 & .505 & 1 & .477 & 1.102 & .843 & 1.442 \\
\hline & Constant & .211 & .379 & .310 & 1 & .578 & 1.235 & & \\
\hline
\end{tabular}

Source: Author

Based on these results we conclude that the active participation of parents in the process of education have positive impact on improving the level of student achievement to a considerable extent, while only participation at family level without the active participation in the sphere of educational process will not affect the improvement of the level of student achievement.

As described above, and after the binary logistic regression, it is indicated that the probability of a higher level of achievement for the analyzed residents is 0.59 and it can be increased by increasing the activity of parents both at the individual and at the school level.

The results indicate that the probability of achieving a better level of achievement is related to the cooperation of parents in the educational - training process for residents is 0.41 (paragraph parents) and teacher 0.59 . The results suggest that parents are less likely to believe that cooperation with the teaching staff of the school can contribute to a better level of student achievement.

\section{Proposed structure of the system support schools}

This section provides a description of the proposed system for DM data for primary schools. The proposed solution is intended to collect data from a plurality of different sources.

Image 1 . shows a proposal for a system with separate components as follows: data sources, data processing and users. 


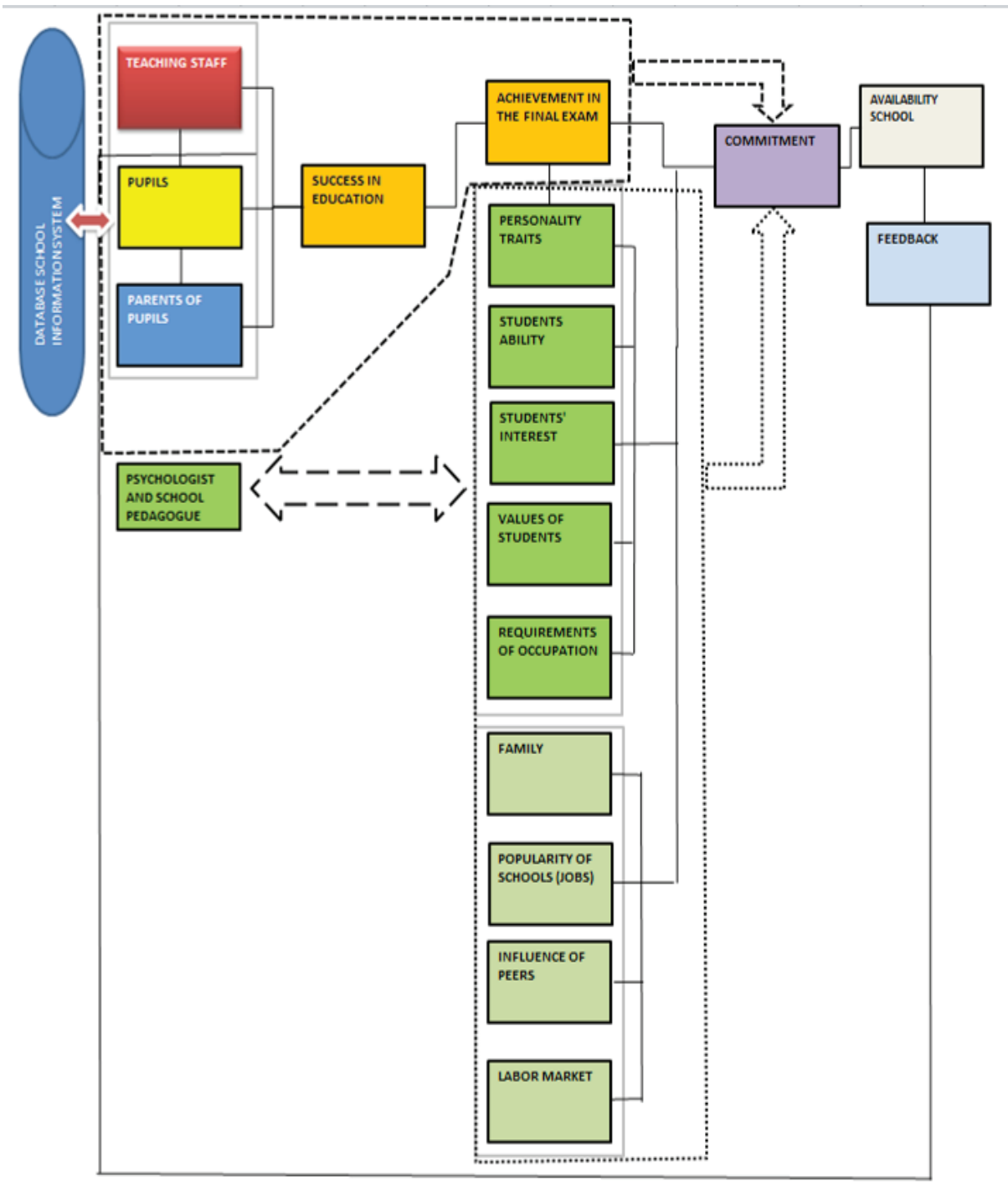

Source: Author

Data sources represent a set of available internal data and open data sources as unique education information system which can be accessed via the corresponding communication interfaces, which can be represented as a Web service.

Data processing is performed by the module that implements the techniques of integration of data from available sources, and data mining techniques of the collected data. Integrated Database is located in this model. Part of the data processing consists of modules for data integration, integrated databases and modules for data mining. 
Data mining module implements the appropriate logic governing of the process of data mining through the application of the method of binary logistic regression of integrated data.

The results of performed analyses should sent to all users in order to undertake measures to improve the educational process and to increase the level of achievement of primary school pupils.

\section{Conclusion}

Primary education plays an important role in economic and social development and all changes and reform processes in this field should lead to improving the economic and social situation of a country. Past reform activities in the primary education system of the Republic of Serbia point the importance of the reform process management as a key factor to improve the quality of education and upbringing process.

Previous theories point out these factor as important ones for the professional commitment of distinguished students: parents, teachers, social circumstances, the current interests of "small graduates", the balance between personal capabilities and chosen profession, friends, etc. (Hossler, Braxton \& Coopersmith, 1989).

Finding patterns, trends and anomalies in data groups, and their summation with the proposed model is one of the biggest challenges of the information age - converting data into information and information into knowledge.

The aim of this study was to develop a genuine, universal methodology of forecasting and decision-making using binary logistic regression, which was confirmed in case of management in order to achieve a satisfactory level of student achievement. Basic existing problems the education policy is faceing are nonexistent connection between economy and research institutions and very small funds and investments into education and training, both on basic level, as well as for education and training of adults (Knezevic \& Veselinovic, 2015). Detecting variables affecting the education, needs of labor market and providing measures that would follow individual before, during and after the education has to be part of educational policy (Južnik Rotar, 2014).

\section{References}

Dietl, J., (1997). Kvalitet obrazovanja na osnovnim strukovnim studijama - Osnovne studije za potrebe biznisa, dosadašnja iskustva i dalje perspective. Łódź, FEP.

Goharian N., \& Grossman D.(2003). Introduction to Data Mining. Illinois Institute of Technology. Chicago.

Han, J.\& Kamber. M. (2001). Data Mining Concepts and Techniques. Morgan Kaufmann Publishers. San Francisco.

Han, J., Kamber, M. \& Pei. J. (2012). Data Mining Concepts and Techniques, Elsevier Inc. Waltham.

Hossler,D.,Braxton,J.,\& Coopersmith,G. (1989). Understanding student college choice. Higher Education Handbook of Theory and Research, (5), 231-288. 
Ilić, V., Nedić, V. (2014). Merenje spremnosti zemalja za razvoj ekonomije bazirane na znanju, Ekonomika, 60 (3), 247-257.

Ilić-Rajković, A. (2015). Reforma produžnih škola u Minhenu i utemeljenje dualnog sistema stručnog obrazovanja, Nastava $i$ vaspitanje, 64 (1), 117-130.

Južnik Rotar, L. (2014). Youth unemployment and entrepreneurship, Ekonomika, 60(4), 43-56.

Knežević, M., \& Veselinović, P. (2015). New education policy's priorities as a function of economic development of Serbia. Ekonomika, 61(1), 151-159.

Mikanović, B. (2014). Ishodi učenja i standardi znanja u osnovnom obrazovanju, Inovacije u nastavi - časopis za savremenu nastavu, 27(1), 84-93.

Milošević, B., Stojković, Z. (2013). Analiza strategije upisa u srednje škole i tendencije zapošljavanja u gradu Nišu, Ekonomika, 59(2), 184-190.

Ngai, E. W. T., Hu, Y., Wong, Y. H., Chen, Y., \& Sun, X. (2011). The application of data mining techniques in financial fraud detection: A classification framework and an academic review of literature. Decision Support Systems, 50(3), 559-569.

Nijkamp P. Siedschlag I. (2011). Innovation, Growth and Competitiveness, Dynamic Regions in the Knowledge- Based World Economy, Springer Heidelberg Dordrecht, London New York.

Paszek, Z. (2012). Metodologija ocene kvaliteta edukacije. Škola biznisa, (3), 18-28.

Sučević, V. \& Kerić, M. (2015). Element ii indikatori za identifikaciju kvaliteta osnovnog obrazovanja, Sinteze, 4, (7), 19-32.

Tomić, M., Spasenović, V. \& Hebib, E. (2015). Linerarni model srednjeg stručnog obrazovanja:primer Austrije. Nastava i vaspitanje, 64(1), 131-144. 